\title{
From Thinking to Raging: Reflexes of Indo-European *Men- Polysemy in Homer
}

\author{
Castrenze Nigrelli \\ Department of Humanities \\ University of Palermo, Palermo, Italy \\ E-mail: castrenze.nigrelli@unipa.it
}

Received: January 17, 2020

Accepted: February 15, 2020

Published: March 1, 2020

doi:10.5296/ijl.v12i2.16257

URL: https://doi.org/10.5296/ijl.v12i2.16257

\begin{abstract}
This paper aims at investigating the semantic value of the verb $\mu \alpha i v o \mu \alpha$ "to rage, to be furious" in Homeric Greek, in order to clarify the striking semantic relationship between the common 'irrational' meaning of the verb and the original 'rational' meaning of the Indo-European root *men- "to think", to which the verb traces back. The corresponding words for $\mu \alpha i v o \mu \alpha 1$ in other Indo-European languages (e.g. OInd. mányatē; Av. mainyeite; OIr. (do)moiniur; OCS mbnjo; Lit. miniu) can be translated as "to think", thus showing an opposite meaning. From a textual analysis of all the occurrences of $\mu \alpha i v o \mu \alpha$ in the Iliad and the Odyssey, the study aims at finding semantic traces of the original meaning "to think" belonging to the Indo-European root *men-, in order to account for the apparently impossible semantic relationship between the verb and the original root. Textual data show a significant polysemy of $\mu \alpha$ ívo $\mu \alpha 1$, which refers to particular psychosomatic dynamics and which can be explained by taking into account the Homeric 'body-mind' association and the role of the heart as the crucial organ which supervises all the vital functions, including the psychic and the cognitive ones.
\end{abstract}

Keywords: Indo-European, Homeric Greek, Semantics

\section{Introduction: State of the Art and Purpose of the Study}

It is well known that the Ancient Greek verb $\mu \alpha$ ivo $\mu \alpha$ prototypically conveys the idea of "raging", "being furious, mad, insane" and is etymologically connected to terms such as $\mu \varepsilon ́ v o \varsigma$ "force, might, rage" and $\mu \alpha v i ́ \alpha$ "madness" (LSJ 2011; Snell 1955-2010). Semantically stative and non-telic, the verb $\mu \alpha i v o \mu \alpha$ basically suggests a state of agitation experienced by the subject, which seems to be highly involved, according to the medium tantum status of the 
verb. Although the common meaning of $\mu \alpha$ ívo $\mu \alpha$ concerns what we would call the irrational dimension, fully conveying the "anger", the fact of "being insane", something striking actually emerges from the linguistic comparison. The corresponding words for $\mu$ aivo $\mu \alpha \mathrm{l}$ in other Indo-European languages convey the idea of "thinking", e.g. OInd. mányate, Av. mainyeite "to think"; OIr. (do)moiniur "to believe, to assume"; OCS mъnjo "to think"; Lit. miniu "to think about, to remember of", therefore showing an opposite meaning, which rather refers to the rational dimension. A similar semantic opposition is also found in other corresponding forms, e.g. $\mu \varepsilon ́ v o \varsigma$ "force, might, rage" vs. OInd. mánas-, Av. manah- "mind". As well as all the terms taken into account so far, the verb $\mu \alpha$ ivo $\mu \alpha$ traces back to the IE root *men- (Note 1), to which some scholars assign the rational meaning "to think" (cf. Rix 2001: 435, who translates einen gedanken fassen). Other scholars add the irrational meaning "to be spiritually aroused" as well (cf. Pokorny 1959: 726, who translates denken; geistig erregt sein; see also Boisacq 1916: 600-601; Walde 1927: 264), in order to account for the irrational component which seems to prevail in Ancient Greek forms, as also shown by other forms, e.g.

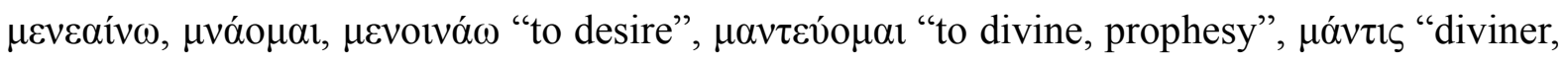
seer, prophet" (Note 2). Starting from Meillet (1897), many scholars have tried to explain the divergence between the irrational frame of the Ancient Greek and the rational frame proper to the original Indo-European root as shown by the other languages. Most of these scholars have hypothesized a semantic split Greek has undergone as opposed to a Proto-Indo-European state (see Monier-Williams 1899; Pokorny 1959; Frisk; 1960-70; Mayrhofer 1963; Chantraine 1968-80). More recently, through a comparative analysis of Homeric Greek and Vedic Sanskrit, Bartolotta $(2003 ;$ 2012) has shown that the opposition that has just been sketched has to be seen rather as in terms of a semantic continuum, based on the polysemy of the IE root *men-, in which both the rational and the irrational dimensions are blurred and mutually connected. She has shown that Homeric and Sanskrit forms actually refer to the

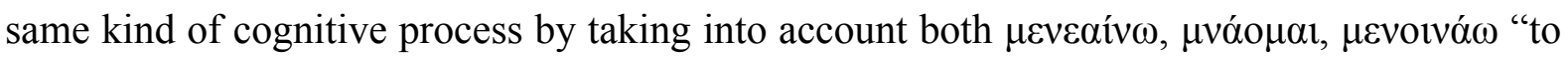

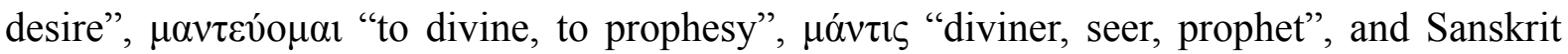
terms connected with the stem man-, like mányatē "to desire", mánas- "mind", which concern "knowledge". In the light of the semantic nucleus the IE root*men-, which can refer to the idea of "having in mind", and its intimate relationship with the IE root *weid- "to see", this cognitive process concerns the physical dimension, so as to involve body, movement, impulse to act, sensorial perception, desire, memory (Note 3). In this perspective, both the rational/irrational and the body/mind dichotomies were likely to be originally blurred and strongly connected to each other in Homer as well as in the Indo-European culture.

Yet, the verb $\mu \alpha i v o \mu \alpha$ still needs further clarification as it represents the polar opposite in reference to the rational meaning, which is inherent to the Indo-European root, within the semantic continuum sketched above. The present study aims at investigating the semantic value of the verb $\mu \alpha$ ivo $\mu \alpha$ in Homeric Greek, which is the oldest state of the Greek language, through a textual analysis of its occurrences in the Homeric poems, in order to account for the apparently impossible semantic relationship between the common 'irrational' meaning of the verb and the original 'rational' meaning of the IE root *men-. The ultimate purpose of the study is to find semantic traces of the original meaning "to think" in the Homeric contexts of

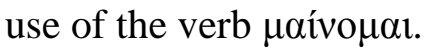




\section{Distribution of $\mu \alpha$ ívo $\mu \alpha$ in the Iliad and the Odyssey}

There are 162 occurrences of $\mu \alpha i v o \mu \alpha$ in Homer, in particular 135 are found in the Iliad and 27 in the Odyssey. In 109 of the total occurrences the verb occurs as a nominal form (i.e. infinitive or participial), while in the other 53 it occurs as a finite form. There is a higher frequency of occurrences as absolute forms $(85 x)$ and as governing an infinitive (73x); only rarely the verb governs a genitive of things $(4 \times)$. Distributional data are summarized in Table 1 .

Table 1. Homeric distribution of $\mu \alpha$ ívo $\mu \alpha \iota$

\begin{tabular}{ccccc}
\hline Total forms & $\begin{array}{c}\text { Finite } \\
\text { forms }\end{array}$ & $\begin{array}{c}\text { Nominal } \\
\text { forms }\end{array}$ & $\begin{array}{c}\text { Absolute } \\
\text { forms }\end{array}$ & $\begin{array}{c}\text { Governing } \\
\text { forms }\end{array}$ \\
\hline $\begin{array}{c}162 \\
\text { (135 Iliad; 27 Odyssey) }\end{array}$ & 53 & 109 & 85 & 77 \\
\hline
\end{tabular}

In particular, the Homeric verbal forms of $\mu \alpha$ ivo $\mu \alpha 1$ are:

- present indicative, $\mu \alpha i ́ v o \mu \alpha r(11 \times)$;

- unaugmented imperfect indicative, $\mu \alpha i ́ v \varepsilon \tau o ~(3 \times)$;

- augmented sigmatic aorist indicative, $\dot{\varepsilon} \pi-\varepsilon \mu \eta ́ v \alpha \tau o(1 \times)$ (Note 4);

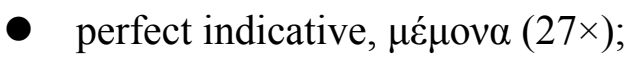

- unaugmented pluperfect indicative, $\mu \varepsilon ́ \mu \alpha \sigma \alpha \nu(8 \times)$;

- present participle, $\mu \alpha \imath v o ́ \mu \varepsilon v o \varsigma(7 \times)$;

- perfect participle, $\mu \varepsilon \mu \alpha \omega ́ \varsigma(101 \times)$;

- perfect imperative, $\mu \varepsilon \mu \alpha \dot{\alpha} \omega(2 \times)$;

- present infinitive, $\mu \alpha i ́ v \varepsilon \sigma \theta \alpha r(1 \times)$;

- present subjunctive, $\mu \alpha i ́ v \eta \tau \alpha \imath(1 \times)$.

Talking about verbal forms in terms of coherent paradigms may be inappropriate in reference to Homeric Greek, since different forms which are traced back to the same root can often exhibit a certain level of independence, which is both formal and semantic. As far as $\mu$ aivo $\mu \alpha$ is concerned, the distribution of the verbal forms shows a dichotomy between those built on the present stem ( $\left.\mu \alpha v_{0}-\right)$ and those built on the perfect stem $(\mu \varepsilon \mu \mathrm{ov}-/ \mu \varepsilon \mu \alpha-)$. This dichotomy proves to be also semantic, as it will be shown.

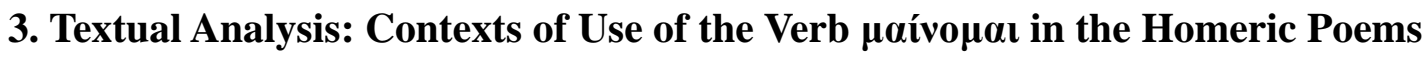

Made by means of the Thesaurus Linguae Grecae (TLG 2000) digital database, the purpose of the textual analysis of all the Homeric contexts of use of the verb $\mu \alpha i v o \mu \alpha t$ is to shed light on the complex semantics of the verb besides its common meaning "to rage, be furious" and to find semantic traces that can account for the original rational meaning "to think" included in the Indo-European root to which the chosen verb traces back. 
In this section the results of the textual analysis on the Homeric poems are presented and discussed. For reasons of space, only a significant selection of examples is taken into account. In each one, noteworthy lexemes are written in bold.

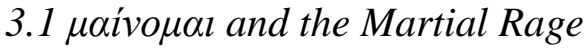

The common meaning of the verb $\mu \alpha i v o \mu \alpha$ is connected to rage, fury, and madness. This can account for the first non-random distributional data: the broad majority of occurrences in the Iliad (135x) rather than in the Odyssey (27x) may be due to the topic of the first poem, i.e. the war between Achaeans and Trojans. War represents a circumstance that forces anybody to be in an incessant state of tension which is both physical and psychic. Most of the Homeric occurrences of $\mu$ aivo $\mu \alpha$ refer in fact to the impetus shown by "furious" heroes during the battle, as illustrated in (1):

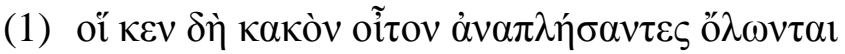

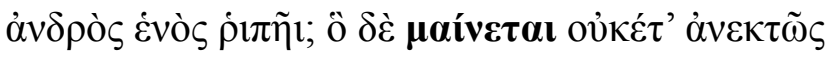

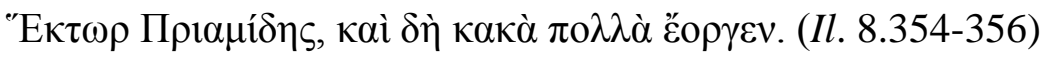

"Now they (scil. Acheans) will certainly perish moving towards an evil fate

because of the rush of a single man: Hector, Priam's son, now rages unbearably

and he does great harm to them"

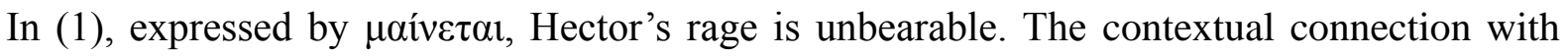
the idea of movement, as shown by the dative $\dot{\rho} \imath \tilde{\eta} 1$ that conveys Hector's hostile "rush" (cf. pí $\pi \tau \omega$ "throw, cast") is noteworthy: the condition expressed by $\mu \alpha i v o \mu \alpha r$ seems to be a state of agitation causing an impulse to act.

The particular agitation indicated by $\mu \alpha$ ívo $\mu \alpha$ is often linked to $\mu \varepsilon ́ v o \varsigma$ "might", i.e. a vital energy, which is physical and psychic at the same time. Sometimes, the furious rage of a hero can be particularly remarkable. This happens especially when a god increases $\mu$ ćvos inside the chest of a hero. Originating from an external agent (i.e. a god), this particular event thus involves heroes internally, making them feel as they were taken by a certain temporary madness ( $\mu \alpha v i ́ \alpha)$ (Note 5) that allows them to accomplish extraordinary acts, as illustrated in (2), in which Diomedes receives a triple increase of his $\mu$ ćvo $\varsigma$ from Athene (cf. also v. 125):

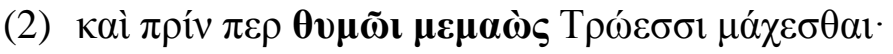

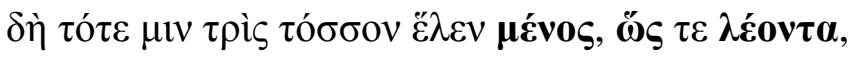

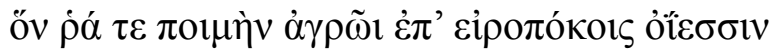

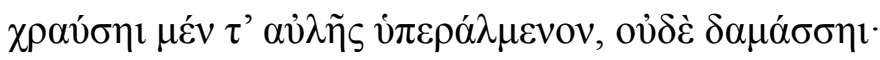

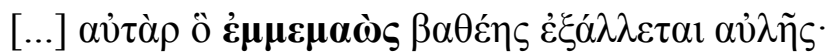

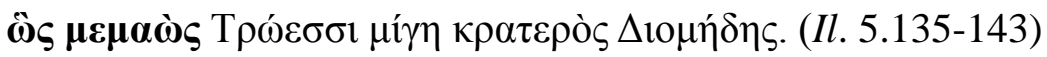

"and before his heart had been eager to fight against the Trojans, 
and then a force laid hold upon him three times as much, as upon a lion,

that a shepherd in the field, guarding his fleecy sheep,

has wounded as he leapt over the fence, but has not killed;

[...] but the eager lion leaps over the high fence:

as eager, mighty Diomedes did and mingled with the Trojans.”

In (2) Diomedes is under the effect of an upsetting force that makes him furious like a

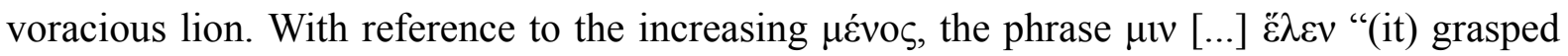
him" refers to the idea of something experienced by the subject because of an external intervention (cf. Dodds 1951). According to the stative value of the Homeric perfect, the perfect participle $\mu \varepsilon \mu \alpha \omega \grave{s}$ refers to the status of somebody who "is eager" to do something. Thus, in the simile with the animal (which is a common Homeric topos to indicate who is

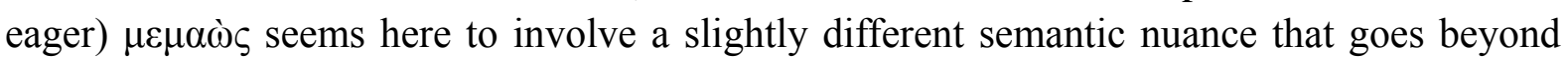
the idea of rage and fury, connecting the verb to the idea of a type of agitation that is an irresistible desire to act (Note 6). It is worthy of note that such an agitation, desire, and impulse is based in the heart, in which the increase of $\mu$ ćvo takes place, as confirmed by its frequent co-occurrence with some anatomical terms, i.e. $\theta v \mu$ ó $\varsigma$ (cf. vv. 135-136), ĩ $\tau$ o $\rho$, $\kappa \rho \alpha \delta i ́ \eta / \kappa \alpha \rho \delta i \eta \eta, \varphi \rho \varepsilon ́ v \varepsilon \varsigma$, relating to that crucial organ which supervises all the vital functions in Homer (see below 3.2-3.3).

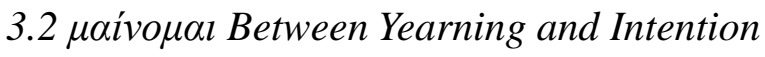

The particular psychosomatic disposition connected to the polysemy of the verb $\mu \alpha$ ivo $\mu \alpha$, as emerged from the examples discussed so far, is further clarified in this section. Such a disposition seems to refer to both burning desire, yearning, and a solid resolution as somehow originated from a rational elaboration. As it will be shown in the following examples, the semantic nuances of $\mu \alpha i v o \mu \alpha$ are often merged and difficult to distinguish, due to the 'body-mind' and 'irrational-rational' associations, which are rather blurred and inextricably connected in Homer (Note 7). For this reason, the broader discourse context is crucial to fully understand the semantic complexity of $\mu$ aívo $\mu \alpha$.

The context in (3) describes the preliminary moment before the battle. In such an introspective situation, heroes are thus forced to get ready for war: on the one hand, they are yearning for gaining the glory by fighting in battle, on the other hand, they are reflecting on the wretched possibility that they are going to die:

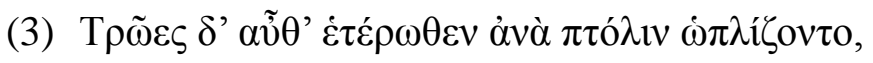

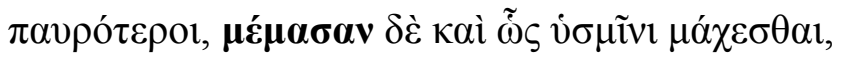

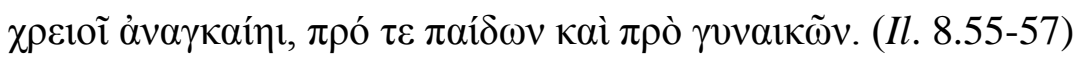

"The Trojans, on their side, armed themselves throughout the city,

they were fewer, yet they were eager to fight in battle 
through utter need, for their children's sake and their wives"

Although the Trojans are worried probably because they are few against the siege of the Achaeans, they are encouraged to fight by utter need (cf. $\chi \rho \varepsilon 10 \tilde{u} \dot{\alpha} v \alpha \gamma \kappa \alpha i \eta \eta)$ : the necessity of defending their sons and wives makes them ready to fight and, indeed, eager to do it (cf. also

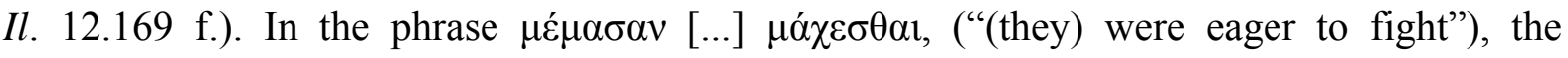
pluperfect $\mu \varepsilon \dot{\varepsilon} \mu \sigma \alpha \nu$ conveys the idea of a desire which is both instinctive and conscious, a wish which originates from both an inner impulse and a rational evaluation of the situation. In other terms, in the meaning of $\mu \varepsilon \dot{\varepsilon} \mu \sigma \alpha \nu$ both desire and will, instinct and reason seem to coexist. Similar observations are valid also in reference to (4), in which the pluperfect

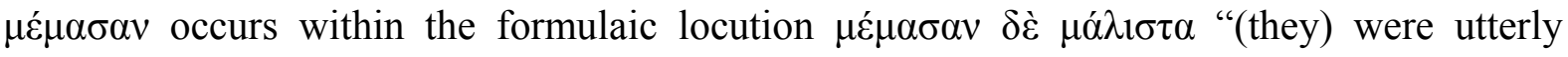
eager":

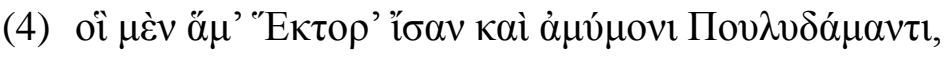

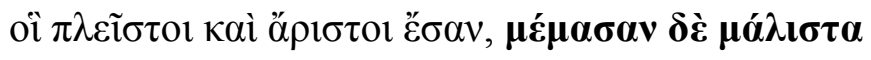

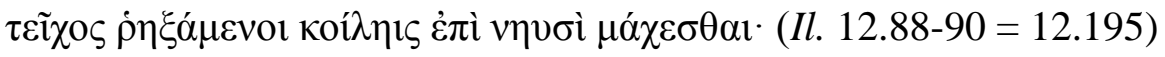

"Some went with Hector and peerless Polydamas,

and they were the most numerous, the best, and were utterly eager

to fight by the hollow ships, once the wall was destroyed."

As shown by the superlative $\mu \alpha \dot{\alpha} \lambda \iota \tau \alpha$ ("exceedingly"), the formulaic locution $\mu \varepsilon \dot{\varepsilon} \mu \alpha \sigma \alpha v \delta \dot{\varepsilon}$ $\mu \alpha \dot{\lambda} \imath \tau \tau \alpha$ in (4) refers to the heroes' yearning to undertake something. Yet, the desire expressed by $\mu \varepsilon \dot{\varepsilon} \mu \alpha \sigma \alpha \nu$ can also be seen as a tenacious resolution, therefore as something rationally determined: the Trojans's will to attack the Achaeans over the wall remains firm, although their horses stopped for fear, forcing the heroes to continue on foot (cf. vv. 49-79) (Note 8).

The idea of a will as involved by the meaning of the analyzed verb is particularly evident in (5), in which the narrative-syntactical context clearly connects the perfect $\mu \varepsilon \mu \alpha \dot{\alpha} \alpha \mathrm{\sigma}$ to the verb (๕) $\theta \dot{\varepsilon} \lambda \omega$ "to want":

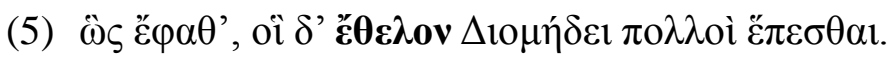

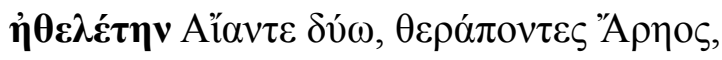

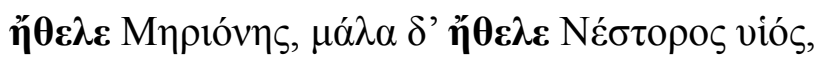

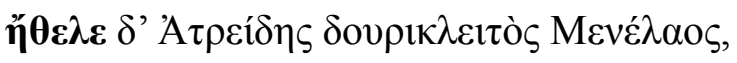

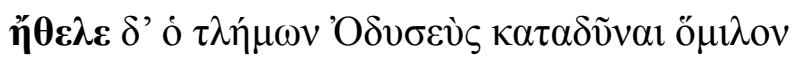

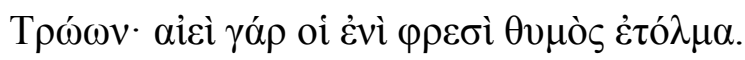

$\tau$

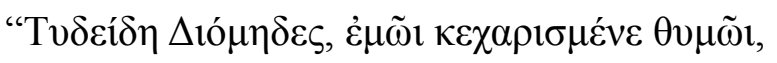

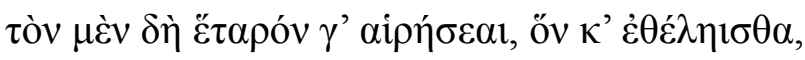




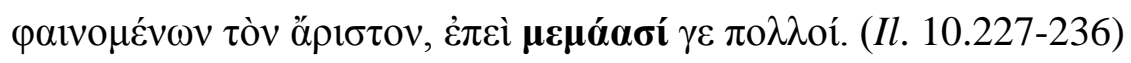

"So he spoke, and many were fain to follow Diomedes.

Fain were the two Aiantes, squires of Ares,

fain was Meriones, and right fain the son of Nestor,

fain was the son of Atreus, Menelaus, famed for his spear,

and fain too was the brave Odysseus to plunge into the throng

of the Trojans: for the heart in his chest was always daring.

Then among them spoke the king of men, Agamemnon:

"Diomedes, son of Tydeus, dear to my heart,

choose as your comrade, whoever you like,

the best of those who offered themselves, for many intended (to follow you)"

Diomedes has volunteered to spy on the enemies at night. The mission is highly risky and he asks whether there is any comrade willing to go with him. Diomedes's words (cf. vv. 220-226) make several Achaeans yearn to participate with him. In (5) there is a list of all those comrades who are ready to take part on the mission. The connection with the verb $(\dot{\varepsilon}) \theta \dot{\varepsilon} \lambda \omega$, which is repeated in anaphora, clearly confirms the semantic value of the perfect $\mu \varepsilon \mu \alpha \dot{\alpha} \alpha \mathrm{r}$ : in reference to the volunteers, in this passage it means "(they) wanted, intended (to do)", therefore conveying their firm will as an attitude or a disposition to act, which is both physical and psychic. In all likelihood, the volunteers are encouraged, on the one hand, by Diomedes's words, and, on the other hand, by considering the glory (as well as the risks) connected to the mission (cf. vv. 211-216).

It is noteworthy that the impulse to do is something that comes from the inside, namely from the heart, and this indeed constitutes the crucial issue to account for the inherent polysemy of

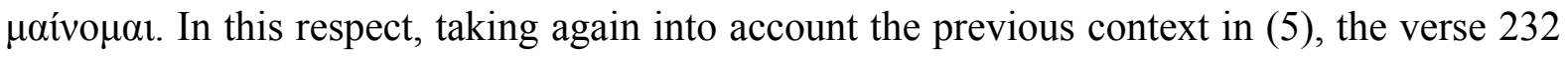
is rather significant:

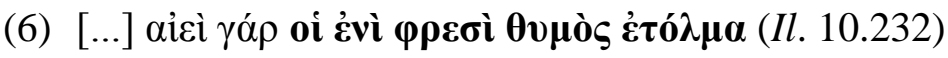

"[...] for the heart in his chest was always daring"

In reference to Odysseus's will to go with Diomedes as a volunteer, Homer says that Odysseus's heart ( $\theta 0 \mu \mathrm{o} \varsigma)$ in his chest or, more precisely, in his pericardium (Ėvì $\varphi \rho \varepsilon \sigma i)$, is always ready to dare to do something. Similarly, Diomedes says that he is urged by his own heart as well, when he for first volunteers for the risky mission of spying on the enemies, as illustrated in (7):

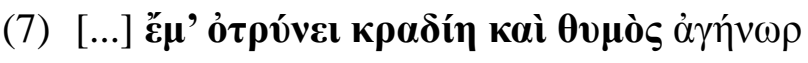

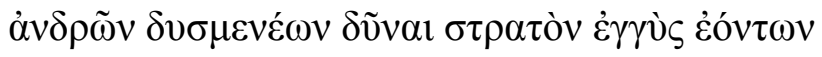




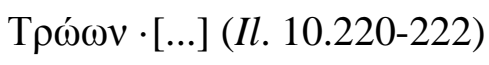

\section{“[...] my heroic heart urges me}

to enter the camp of the enemies, that are near,

the Trojans; [...]"

Diomedes's will to volunteer comes out as an encouraging impulse (cf. ó $\tau \rho v ́ v \omega$ "to stir up,

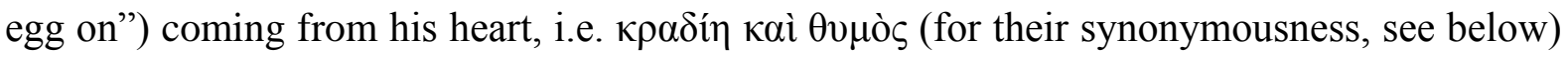
(Note 9).

Furthermore, the particular psychosomatic status expressed by the pluperfect $\mu \varepsilon \varepsilon^{\prime} \alpha \sigma \alpha v$, in reference to heroes' yearning to fight - cf. (2)-(4) - is based in their hearts as well, as illustrated in (8)-(9):

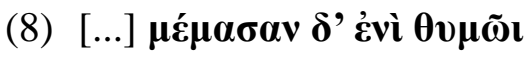

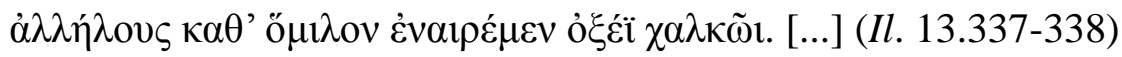

"[...] and they were eager in their hearts

to slay one another in the throng with the sharp bronze."

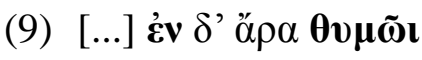

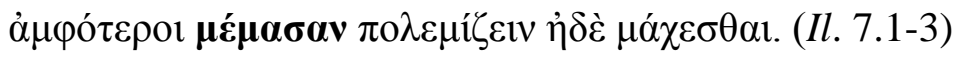

“[...] and in their hearts

they were both eager to struggle and fight."

The co-occurrence of physical terms proves that the heart plays a central role on the psychosomatic dynamics involved by the meaning of the verb $\mu \alpha$ ívo $\mu \alpha$. According to the Homeric biological concept, the heart is the complex human organ whose parts supervise all the vital functions, including the psychic and the cognitive ones, jointly and without any functional distinction, as confirmed by the frequent terminological interchangeability between Homeric terms such as $\theta v \mu$ ó $\varsigma, \kappa \rho \alpha \delta i ́ \eta / \kappa \alpha \rho \delta i ́ \eta, ~ \varphi \rho \varepsilon ́ v \varepsilon \varsigma, ~ \tilde{\eta ் \tau o \rho, ~ i n ~ s p i t e ~ o f ~ t h e i r ~}$ reference to different elements. In the Homeric human being, the motion of the sanguineous life/motion principle (i.e. $\theta v \mu$ ó $\varsigma$ ) inside the heart (i.e. $\kappa \rho \alpha \delta i ́ \eta / \kappa \alpha \rho \delta i ́ \eta ~ o r ~ \tilde{\eta ் \tau o \rho) ~ i s ~ b a s i c a l l y ~}$ propagated to the pericardium (i.e. $\varphi \rho \varepsilon ́ v \varepsilon \varsigma$ ), in which the heart is contained, so giving rise to emotions, desires, wills, reasoning, thoughts, and, if this motion also spreads to other body parts, to movements, actions, and speech (Laspia 1996: $107 \mathrm{ff}$.) (Note 10). All the human functions depend on the heart. Therefore, there is not a real distinction between body and mind in Homer, the only dimension which he recognizes for the self is the physical one. In other words, what will be later seen as psychic, mental, spiritual, cognitive processes is actually a physical motion of the heart in Homer, and this accounts for that in Homer the psychic lexicon is basically the physical one (cf. Onians 1951; Vivante 1956; Laspia 1996; Spatafora 1999; Bartolotta 2012; Levko 2016). Hence, the semantic complexity of the verb $\mu \alpha i v o \mu \alpha$ refers to that state of agitation resulting from the motion of the heart in the chest, 


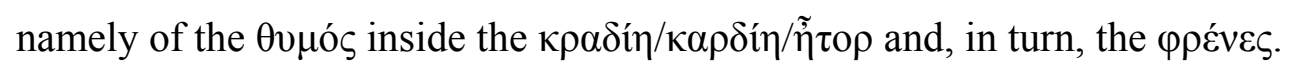

\section{3 paivoual and the Thought Process}

In the light of the Homeric concept of the cardiac system, the following examples present particular uses of the verb $\mu \alpha i v o \mu \alpha$ which show traces of the rational original meaning "to think", proper of the Indo-European root *men-.

In (10), the perfect $\mu \varepsilon \dot{\mu} \mu \mathrm{ov \varepsilon}$ clearly refers to a cognitive process which involves the movement of the $\varphi \rho \varepsilon \dot{v \varepsilon \varsigma:}$

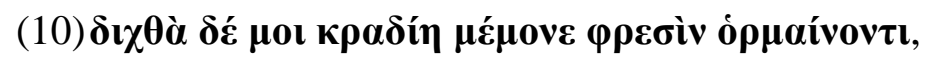

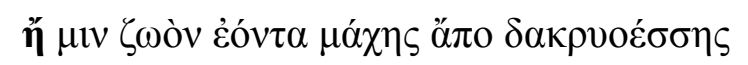

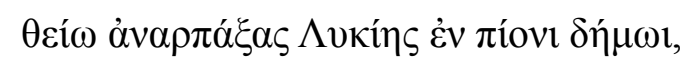

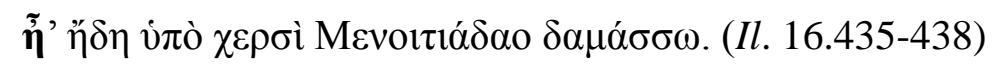

\section{"My heart thinks in two different ways as it ponders with its revolving pericardium,}

whether I shall snatch him up while he is still alive

and set him afar from the tearful battle and take him to the rich land of Lycia

or whether I shall slay him now by the hand of the son of Menoetius"

In (10) Zeus tells Hera that he is torn: he would like to help Sarpedon, a hero which is dear to him, but he has forbidden everyone from helping any hero in the battle. Zeus is actually pondering and he is literally divided: the adverb $\delta \imath \chi \theta \dot{\alpha}$ "in two (ways)" actually refers to the

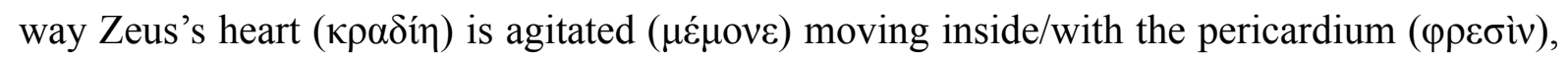
so giving rise to two divergent hypotheses, two different thoughts. The cognitive process expressed by $\mu \varepsilon \dot{\mu} \mu \mathrm{v} \varepsilon$ lies in Zeus's heart movement, as also shown by the significant connection with the motion verb o $\rho \mu \alpha i v \omega$ "to turn over; revolve anxiously in the mind; think, ponder" (which is etymologically connected to ó $\rho \alpha \dot{\alpha} \omega$ "to set in motion", ó $\rho \mu$ "rapid motion

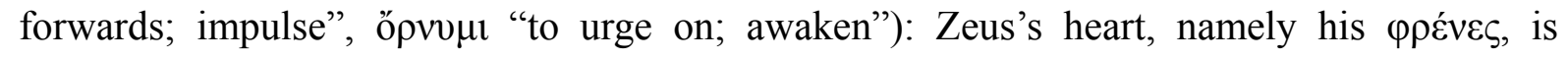
actually turning over two hypotheses. Conveyed by the adverb $\delta \imath \theta \dot{\alpha}$, the twofold thinking of Zeus is also linguistically reflected when he verbalizes his divergent thoughts, as shown by the particles $\ddot{\eta}[\ldots] \tilde{\hat{\eta}}$ “whether... whether or".

Similarly, in (11) the perfect $\mu \varepsilon$ évos expresses the idea of pondering, as also proved by the

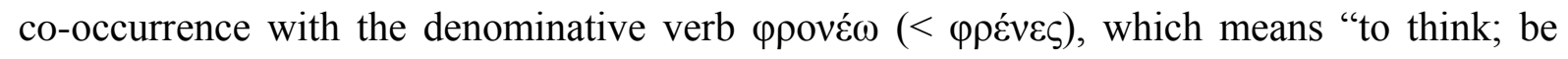
minded":

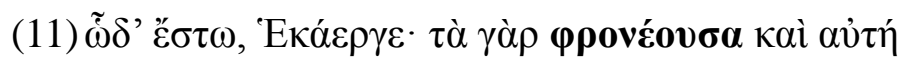

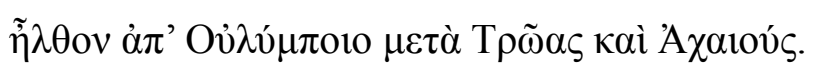

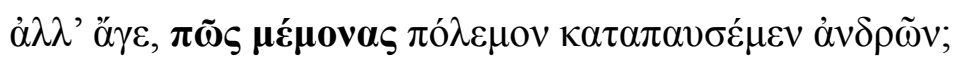

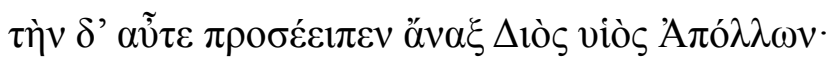




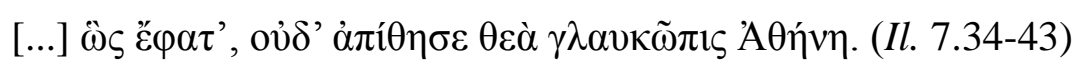

"So be it, you god that work afar; so thinking myself,

I came from Olympus to the midst of Trojans and Achaeans.

But come, how do you intend to put an end to the battle of the warriors?

Then in answer to her spoke king Apollo, son of Zeus:

[...] So he spoke, and the goddess, flashing-eyed Athene, was convinced"

In (11) Apollo intends to stop the battle and Athene agrees with him, as expressed by the

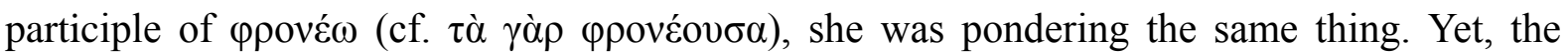
goddess asks Apollo how $(\pi \tilde{\omega} \zeta)$ he intends to do it. In other terms, Athene wants to know what is the way Apollo has thought of. As proved by the larger discourse context, the semantic value of the perfect $\mu \varepsilon$ évas in (11) is "(you) have pondered, thought, planned": in fact Apollo tells ( $\pi \rho \circ \sigma \varepsilon \dot{\varepsilon} \pi \varepsilon v$ ) Athene a real detailed plan (cf. vv. 38-42). According to the stative value of the Homeric perfect, the cognitive activity expressed by $\mu \varepsilon$ covas can be explained as a state resulting from a concluded action, with reference to the heart agitation: "(you) are aroused (in your heart)" > "(you) have thought" > "(you) intend (to do)". As in (10), also in (11) what is thought is also verbalized: by explaining his plan, Apollo convinces the goddess.

In the light of (10)-(11), in (12) the verb $\mu \alpha i v o \mu \alpha$ co-occurs with $\varphi \rho \varepsilon ́ v \varepsilon \varsigma$ in reference to a state of agitation which seems to reflect thought process, rather than rage or madness:

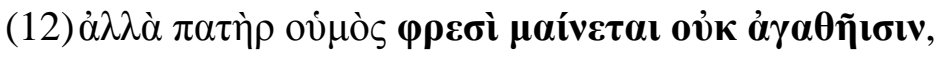

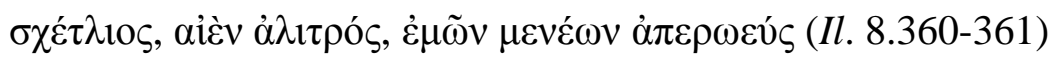

"but my father thinks with evil heart,

merciless that he is, always wicked, a thwarter of my intents"

Athene would like to see Hector dead, but her father Zeus does not agree with her. In (12), Athene says that Zeus has a bad disposition to her purposes: the goddess literally says that

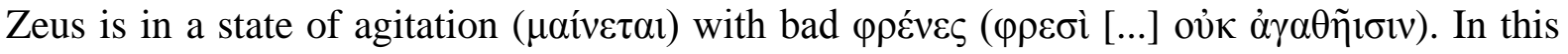
perspective, Zeus's disposition, which is certainly mental, can be understood as resulting from bad movements of his heart (namely, his $\varphi \rho \varepsilon ́ v \varepsilon \varsigma$ ). Furthermore, it is noteworthy that

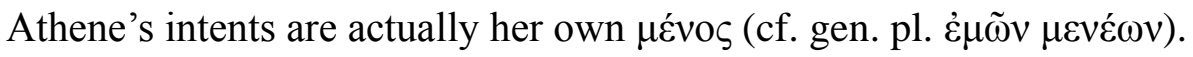

\section{Conclusion}

From the textual analysis of the Homeric contexts of use of the verb $\mu \alpha$ ivo $\mu \alpha$, its complex polysemy has been clarified. According to the rational meaning included in the Indo-European root *men- to which the verb traces back, the semantic field of $\mu \alpha$ ívoual including also those forms built on the perfect stem $(\mu \varepsilon \mu \mathrm{ov}-/ \mu \varepsilon \mu \alpha-)$ - involves a range of nuances, i.e. "to rage, be furious", "to be eager", "to desire", "to be fain", "to intend", "to think", which are often merged. All these meanings refer to a state of agitation (basically 
associated with something to do) which is strongly connected to that complex organ which is

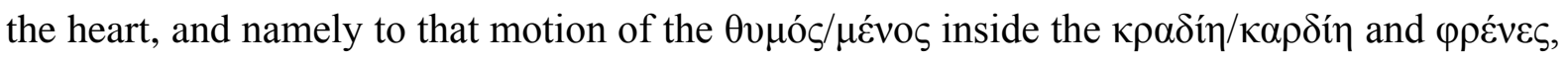
which supervises all human functions in Homer, including cognitive processes.

Similarly to the semantic value of other Archaic Greek forms tracing back to the Indo-European root *men-, it does not actually seem to be appropriated to distinguish between concepts such as body and mind, or irrational and rational, which are rather inextricably merged in the original meaning of the root and, thus, in the early Indo-European culture.

\section{References}

Ahonen, M. (2019). Ancient philosophers on mental illness. History of Psychiatry, 30(1), 3-18. https://doi.org/10.1177/0957154X18803508

Bartolotta, A. (2003). Towards a Reconstruction of Indo-European Culture: Semantic Functions of IE *men-. In K. Jones-Bley, M. E. Huld, A. Della Volpe, \& M. Robbins Dexter (Eds.), Proceedings of the Fourteenth Annual UCLA Indo-European Conference (pp. 37-62). Washington DC, Institute for the Study of Man Inc.

Bartolotta, A. (2012). L'occhio della mente. Un'eredità indoeuropea nei poemi omerici. Palermo: Officina di Studi Medievali.

Beekes, R. (2009). Etymological Dictionary of Greek. Leiden: Brill.

Boisacq, E. (1916). Dictionnaire étymologique de la langue grecque. Paris: Klincksieck.

Bonfante, G. (1979). MENTE=MANÍA. Rendiconti dell'Accademia Nazionale dei Lincei. Classe di Scienze Morali, Storiche e Filologiche, 8(34), 7-12, 325-327.

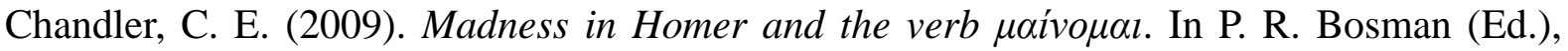
Acta Classica, Supplementum III, Mania: Madness in the Greco-Roman World (pp. 8-18). Pretoria, V\&R Printing Works.

Chantraine, P. (1968-1980). Dictionnaire étymologique de la langue grecque. Paris: Klincksieck.

Dodds, E. R. (1951). The Greeks and the irrational. Berkeley-Los Angeles: University of California Press.

Ebeling, H. (1885). Lexicon Homericum. I-II. Leipzig: Teubner.

Frisk, H. (1960-1970). Griechisches Etymologisches Wörterbuch. Heidelberg: Carl Winter.

Laios, K. (2018). Psychosomatic disorders in ancient Greek medicine. Psychiatriki, 29(2), 130-136. https://doi.org/10.22365/jpsych.2018.292.130

Laspia, P. (1996). Omero linguista. Voce e voce articolata nell'enciclopedia omerica. Palermo: Novecento.

Levko, O. V. (2016). Somatic means of emotion verbalization in Ancient Greek and Ukrainian linguocultures. Science and Education a New Dimension. Philology, 4(26), 30-33.

LSJ. (2011). The online Liddell-Scott-Jones. Greek-English lexicon. Irvine: University of California. 
Mayrhofer, M. (1963). Kurzgefasstes etymologisches Wörterbuch des Altindischen. Heidelberg: Carl Winter Universitätsverlag.

Meillet, A. (1897). De Indo-Europaea radice *men- "mente agitare”. Lutetiae-Parisiorum: Bouillon.

Monier-Williams, M. (1899). A Sanskrit-English Dictionary. Dehli: Motilal Banarsidass.

Onians, R. B. (1951). The Origins of European Thought About the Body, the Mind, the Soul, the World, Time, and Fate. Cambridge: Cambridge University Press.

Perdicoyianni-Paléologou, H. (2009). The vocabulary of madness, from Homer to Hippocrates. Part 1: The verbal group of $\mu \alpha i v o \mu \alpha$. History of Psychiatry, 20(3), 311-339. https://doi.org/10.1177/0957154X08337643

Pokorny, J. (1959). Indogermanisches Etymologisches Wörterbuch. Bern-München: Francke Verlag.

Porzio Gernia, M. L. (1989). Ricostruzione linguistica e ricostruzione culturale: la funzione delle radici *men- e *wat- nell'antica cultura indoeuropea. Quaderni dell'Istituto di Glottologia, 1, 79-91.

Rix, H. (2001). Lexikon der indogermanischen Verben. Wiesbaden: Reichert Verlag.

Rohde, E. (1970). Psiche. Bari: Laterza.

Roth, P. (1988). Etymology of the Term Mantis ("Prophet") in Ancient Greek. In R. L. Hadlich, \& J. D. Ellsworth (Eds.), East meets West: Homage to Edgar C. Knowlton Jr. (pp. 237-245). Honolulu, University of Hawaii.

Schwyzer, E. (1953). Griechische Grammatik. Munich: Beck Verlag.

Snell, B. (1955-2010). Lexikon des frühgriechischen Epos. Göttingen: Vandenhoeck \& Ruprecht.

Spatafora, G. (1999). I moti dell'animo in Omero. Roma: Carocci.

TLG. (2000). Thesaurus Linguae Grecae. A Digital Library of Greek Literature. Irvine: University of California.

Ustinova, Y. (2018). Divine mania: alteration of consciousness in ancient Greece. London: Routledge. https://doi.org/10.4324/9781315098821

Vivante, P. (1956). Sulle designazioni omeriche della realtà psichica. Archivio glottologico italiano, 41, 113-138.

Walde, A. (1927). Vergleichendes Wörterbuch der indogermanischen Sprachen. I. Berlin-Leipzig: Walter de Gruyter.

\section{Notes}

Note 1 . The present stem of $\mu \alpha i v o \mu \alpha$ is constructed adding the *-yo suffix to the zero grade *mn- of the IE root *men-.

Note 2. Both meanings "to think of; remember" are given in Beekes (2009). Ebeling (1885: 
1008) adds the meaning "to stand" (cf. "et cogitandi et furendi et manendi"), thus linking the root to Gr. $\mu \varepsilon \dot{v} \omega$ and Lat. maneo, even though other scholars doubt it (Walde 1927; Pokorny 1959; Rix 2001).

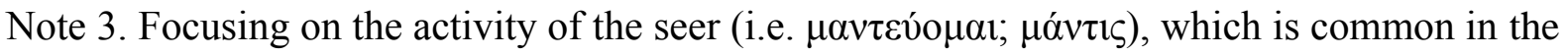
Indo-European world and traditionally related to the idea of a god-given prophetic rage (see, among others, Dodds 1951; Schwyzer 1953: 694; Frisk 1960-70: 172; Chantraine 1968-80: 665; Bonfante 1979: 327; Roth 1988: 238; Porzio Gernia 1989: 82; Snell 1955-2010; more recently, see also Ustinova 2018), she shows that seer's activity actually concerns a particular, albeit human, cognitive activity connected to a specific organ, a sort of mind eye (cf. OInd. mánas-), as also shown by the overlap between the terms for the poet and the seer in many Indo-European languages, e.g. Lat. vates; OIr. fili (see Bartolotta 2003; 2012 for further details; see also Rohde 1970).

Note 4. Besides غ̇ $\pi \varepsilon \mu \eta \dot{v} \alpha \tau$, prefixed form with the preposition $\dot{\varepsilon} \pi(i)$ - "to, towards", there are occurrences $(13 \times)$ in which $\mu \alpha i v o \mu \alpha$ occurs in prefixed form with $\dot{\varepsilon} v$ - "in".

Note 5. On the concept of madness in Ancient Greek culture, see, among others, Chandler (2009); Perdicoyianni-Paléologou (2009); more recently, see also Laios et al. (2018); Ahonen (2019).

Note 6. Some verse before, Diomedes is assimilated to a river in flood (cf. vv. 87-88). Besides the case of Diomedes, another excellent example of heroic fury/madness is that of Hector, which is assimilated to Ares and to a destructive fire (cf. Il. 15.605-606).

Note 7. Also according to philosophical speculation, at least from Aristotle onwards, both an irrational and a rational impulses are involved in the psychic processes which generate choices and will.

Note 8. Similar semantic nuances are also found in contexts which are outside of that of war/battle (cf. the use of the perfect $\mu \varepsilon \dot{\varepsilon} \mu \mu \varepsilon \varepsilon v$ in Il. 9.640-642). The formula $\mu \varepsilon \dot{\mu} \mu \alpha \sigma \alpha \delta \dot{\varepsilon}$ $\mu \alpha ́ \lambda ı \sigma \tau \alpha$ also occurs at v. 90 in a rather similar context, in which the co-occurrence of the verb $\mu \varepsilon \rho \mu \eta \rho i \zeta \omega$, which means both "to think" and "to think about; to be anxious or thoughtful", is significant (cf. Il. 12.195-200).

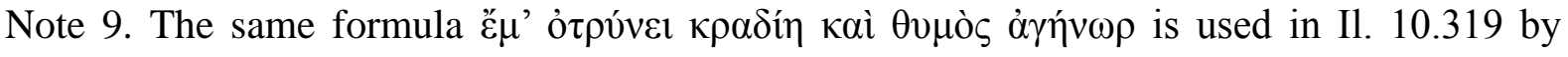
Dolon, the Trojan spy that voluntarily goes to spy on the Achaeans.

Note 10. In Homer, $\mu \varepsilon \dot{v} \nu \varsigma$ basically represents an increase of $\theta v \mu$ ó $;$; for further details on the Homeric biological concept, see Laspia (1996).

\section{Copyrights}

Copyright for this article is retained by the author(s), with first publication rights granted to the journal.

This is an open-access article distributed under the terms and conditions of the Creative Commons Attribution license (http://creativecommons.org/licenses/by/4.0/) 